International Journal of Canadian Studies

Revue internationale d'études canadiennes
INTERNATIONAL JOURNAL OF CANADIAN STUDIES

REVUE INTERNATIONALF D'ÉTUDES CANADIENNES

\title{
Giving Hockey's Past a Future: When Identity Meets Demography in Canadian Sports
}

\section{Jack Jedwab}

Numéro 35, 2007

Sport, Identity and Social Division in Canada

Sport, identités et clivages sociaux au Canada

URI : https://id.erudit.org/iderudit/040770ar

DOI : https://doi.org/10.7202/040770ar

Aller au sommaire du numéro

Éditeur(s)

Conseil international d'études canadiennes

ISSN

1180-3991 (imprimé)

1923-5291 (numérique)

Découvrir la revue

Citer cette note

Jedwab, J. (2007). Giving Hockey's Past a Future: When Identity Meets

Demography in Canadian Sports. International Journal of Canadian Studies /

Revue internationale d'études canadiennes, (35), 191-214.

https://doi.org/10.7202/040770ar d'utilisation que vous pouvez consulter en ligne. 


\section{Jack Jedwab}

\section{Giving Hockey's Past a Future: When Identity Meets Demography in Canadian Sports}

\section{Introduction}

The term "hockey nation" is being increasingly used to refer to Canada because hockey is widely regarded as a fundamental element of Canadian identity. As the principal architect of a motion to have hockey recognized as the country's official sport, federal Member of Parliament Nelson Riis remarked that:

It is safe to say that hockey matters to all of us, in Quebec and the rest of Canada. It is part of our culture. It is key to the understanding of Canada. It is the perfect game on the perfect Canadian medium in the perfect Canadian season. We are a northern people and hockey is a northern sport. It is certainly fair to say it is much more than a game in our country." (Parliamentary Debates, House of Commons Canada, National Sport Act Statement by Members Private Members' Business, Wednesday, April 27, 1994-hereafter Parliamentary Debates, April 27, 1994) ${ }^{1}$

Hockey's dominance in Canada is rooted in the country's history; ${ }^{2}$ it is played and watched by an important number of Canadians and Canada has achieved international success in the sport. Hockey has been widely described as the sport that unites all Canadians across regions, language groups, and ethnic origins. But this idea has not gone unchallenged, whether it be from the historical perspective of hockey's status as the country's official sport or from the perspective of the growing attention given to other sports by an increasingly diverse population. The following discussion will consider how recent debates on Canadian identity have influenced hockey's status as the country's principal unifying sport. This discussion will include the 1994 debate in the House of Commons over the recognition of hockey as Canada's official sport and present the case for according a similar status to lacrosse. The discussion will also exam- 
ine the growing impact of demographic changes on these sports played and viewed by more and more Canadians.

Discussions on the role of hockey in Canadian history and its contribution in promoting a better understanding among Canadians of diverse backgrounds sometimes appear to be parallel national debates on identity, most notably as it pertains to the recognition of the country's distinct characteristics. Indeed, it is against the backdrop of such debates that we are able to better understand the exchanges leading up to the adoption of Bill C-212, which on May 12, 1994, recognized hockey as the county's official winter sport and lacrosse as its official summer sport. An analysis of the discussions in the Canadian House of Commons related to this recognition reveals that the underlying motivation for conferring such status was to support Canadian unity. Elected representatives from the federalist parties made no secret of the fact that for them Bill C-212 represented an important contribution to Canadian unity at a time when the threat of Quebec separation was a matter of growing concern.

\section{Establishing the Context: Hockey and the Debate over Canadian Identity}

The move to have hockey and lacrosse recognized as Canada's official sports in 1994 was not the first attempt to have Parliament recognize hockey as Canada's official or national sport. However, in this instance, it occurred as part of an attempt to identify initiatives aimed at fostering Canadian unity following a number of setbacks in the country's ongoing constitutional debate.

In June 1987, a draft of the Meech Lake Accord had clearly stated that any interpretation of the Canadian Constitution must recognize that Quebec forms a distinct society within Canada. It affirmed the role of the Quebec government and legislature to "preserve and promote the distinct identity of Quebec."3 Approximately one year before it was slated to take effect, the Accord's near unanimous approval disintegrated as the vigorous opposition from certain provincial leaders in Manitoba, New Brunswick, and Newfoundland grew. A number of reasons have been given for the failure of the Accord, but its failure to satisfactorily address the issue of Aboriginal rights motivated opposition from Aboriginal leaders to the Accord. In 1990, a member of the Manitoba Legislative Assembly, Elijah Harper, held up an eagle feather in the province's legislature to symbolise his refusal to endorse the Meech Lake Accord, thereby torpedoing the deal, which required unanimous consent from that body. In Quebec, support for Quebec sovereignty reached unprecedented heights following the failure of the Meech Lake Accord. 
In another area, a land dispute opposing the Mohawk nation and the town of Oka, Quebec, unfolded from early March to the end of September 1990. The conflict resulted in three deaths and, although it initially fuelled tension between Aboriginals and non-Aboriginals, it ultimately raised public awareness and sympathy for Aboriginal concerns in much of Canada.

Under the leadership of Prime Minister Brian Mulroney, the Conservative government pursued constitutional change and, in 1992, proposed a new deal, the Charlottetown Accord. Whereas the Meech Lake Accord had focussed more specifically on the recognition of Quebec's distinct character, the Charlottetown Accord was an attempt to respond to other constituencies that also desired some form of recognition. Through the "Canada Clause," it also proposed the recognition of self-government for Aboriginals and provided greater empowerment to Western Canada through the reform of Canada's Senate.

Although the Charlottetown Accord was supported by the provincial and territorial governments, and representatives from the Assembly of First Nations, with the exception of New Brunswick, the majority of the voters in each of the provincial referendums rejected the Charlottetown Accord. The more popular amongst the many interpretations of the causes for this failure is the rejection by Canadians of what they saw as too large a concession to Quebec and the rejection by Quebecers of what they perceived as too little when compared with the failed Meech Lake Accord. In the federal election of the following year, the Conservatives were left with only two seats in the House of Commons while the Liberals, under Jean Chrétien, formed a majority government with 177 seats. Much of the Conservatives' support went to two regional parties: the Western Canadian-based Reform Party took 52 seats while the Bloc Québécois, committed to Quebec sovereignty, won 54 seats with approximately half the vote in that province. Although it ran candidates only in Quebec, its performance and the fragmentation of the federal vote resulted in the Bloc becoming Canada's Official Opposition. Meanwhile in Quebec, the sovereignist Parti Québécois was favoured to win the election anticipated in the fall of 1994 . This meant that the promised referendum on Quebec sovereignty would be held before the end of 1995 .

The aforementioned political circumstances clearly influenced the thinking and actions of parliamentarians struggling to deal with the threat to Canadian unity during that period. Hence, while Bill C-212 recognized hockey as an official sport principally to foster unity between Anglophone and Francophone Canadians, by also recognizing lacrosse, it included the Aboriginal in this parliamentary acknowledgement. Given the rationale behind recognizing the summer sport, Bill C-212 was sort of a "Canada Clause." 


\section{Hockey Patriotism and Canadian Identity}

The parliamentary discourse in favour of recognizing hockey as an official sport essentially consisted of four arguments: (1) the game was invented in Canada and its creation was an important moment in Canada's history; (2) hockey is played and watched by nearly all Canadians; (3) hockey unites all Canadians regardless of their linguistic or ethnic origins and (4) Canada's world leadership in hockey has resulted from the cooperation of persons of various backgrounds and more specifically of English and French Canadians. The Member of Parliament (MP) for Kamloops (British Columbia) Nelson Riis, who spearheaded the legislation, was quite explicit in invoking national unity as justification for the adoption of the Bill. Riis declared that:

We look at the present and to the future and see the need to bring Canadians closer together. We need symbols that represent Canada as a whole. We need to build on what we have. Hockey and lacrosse can play a part in furthering pride in our land and our unity. (Parliamentary Debates, April 27, 1994)4.

For her part, MP Sharon Hayes stated that:

This discussion encompasses much more than the pros and cons of two Canadian sports. Rather it is an opportunity for us as members of Parliament to raise a rallying point to help us further define ourselves as Canadians. I assert that by naming Canada's national sports, with which we identify parts of our history, our present reality and a future that can bring all Canadians a step closer together. ${ }^{5}$ (Parliamentary Debates, April 27, 1994)

The discourse related to the recognition of lacrosse as an official sport of Canada was quite different. While the recognition of hockey as Canada's official sport was seen as a response to the contributions of English and French Canadians to national identity, the recognition of lacrosse as an official sport was an attempt to include Aboriginals in this undertaking. The recognition of lacrosse as an official sport responded mainly to one of the criteria used by those advocating the recognition of hockey as Canada's official sport, namely its roots in Canada's history. Not surprisingly, the debate stirred little interest in Canada's international achievements in this sport, in its role in fostering unity between Canadians of diverse origins or in the extent to which it is watched and played by Canadians. In fact, lacrosse was not viewed discursively as a nation-building sport in the manner that hockey was described in the remarks made by elected officials. Indeed many of the parliamentarians admitted to their ignorance about lacrosse and its place 
in the country's history. The debate on the Bill that ultimately recognized both hockey and lacrosse as Canada's national sports gave several elected officials an opportunity to reaffirm their pride in Canada. This is reflected in the many statements in reference to hockey that were made during the discussions.

\section{Hockey and the Founding of Canada}

During the debate of Bill C-212, Sharon Hayes noted that most countries chose a national sport created in that country. In this regard, hockey was described as a sport as old as Canada itself. A combination of bandy, originally from England, shinty, originally from Scotland, hurley, originally from Ireland, and lacrosse borrowed from the native Indian population, hockey has a multi-ethnic legacy. The debate among historians regarding the exact origins of hockey in Canada was not resolved by parliamentarians. Authorities in Montreal have emphatically declared that their city is the original home of ice hockey. Tracing this "uniquely" Canadian sport back to the early $19^{\text {th }}$ century, MP Hayes noted that the hockey most familiar to Canadians today was first introduced in Montreal by J.G.A. Creighton, a McGill University student. The first world hockey championship was held in Canada in 1883. Another MP, Pat O'Brien, said he was proud to inform the House that although many early hockey players were French Canadians and the sport was founded in Montreal, it was developed by an Irish Canadian by the name of Ambrose O'Brien (Parliamentary Debates, April 27, 1994).

Hockey is rooted in Canada's history as well as in its geography. Parliamentarians were inspired by sports historian Bruce Kidd who wrote: "Hockey is the Canadian metaphor. The rink is a symbol of this country's vast stretches of water and wilderness, its extremes of climate, the player a symbol of our struggle to civilize such a land. Unsure as we are about who we are, we know at least this about ourselves: We are hockey players and we are hockey fans.'. "It is safe to say that hockey matters to all of us, in Quebec and the rest of Canada. It is part of our culture. It is key to the understanding of Canada... We are a northern people and hockey is a northern sport" 7(Parliamentary Debates, April 27, 1994).

\section{Every Canadian is a Hockey Player?}

Yet another justification for recognizing hockey as an official sport was the extent to which it is watched and played by Canadians. As parliamentarians remarked, hockey is the preferred sport of a majority of Canadian households and it is played in every region of the country. As one MP observed, there is an organized hockey event in virtually every Canadian community, in large cities and in humble villages. It was also pointed out that hockey is 
an inclusive sport and that it is the fastest growing sport played by women in Canada. When Bill C-212 was passed, the Canadian women's national team had already won three consecutive world championships, the last one just two weeks before. MP Dennis Mills summed up the debate when he said: “...although its symmetry is far from perfect hockey does far better than most [sports] in cutting across social divisions, young and old, rich and poor, urban and rural, French and English, east and west, able and disabled"8 (Parliamentary Debates, April 27, 1994).

\section{Canada World Leader in Hockey}

Parliamentarians pointed out that there was nothing more identifiably Canadian to the rest of the world than the game of hockey. Canadians had successfully competed internationally in both amateur and professional circuits. Many agreed that nations achieve international status and recognition through sports. Canada claims to have exported the game of hockey to more than twenty countries. During the debate, parliamentarians referred to the 1972 summit series that pitted Canada against the Soviet Union, an event credited by some analysts as having eased tensions between the West and East during the Cold War. In this particular instance, sports do appear to have eased political tensions. The dramatic victory of Canada over the Soviet Union has long been seen as a pivotal moment in our pursuit of national pride and unity, and this in spite of the fact that it took place during a tumultuous political era that coincided with the emergence of the sovereignist Parti Québécois.

\section{Hockey Unity}

A well-known Canadian hockey broadcaster, the late Foster Hewitt, once stated that: "In our country while hockey is usually played for sheer enjoyment, its outdoor rinks and enclosed arenas are meeting places for youths of all origins where race, culture and creed are forgotten. The Stewarts, Kellys, Smiths, Beliveaus, Delvecchios, Mahovlichs, the Ullmans and Howes combine for the glory of the team and in the process, Canada gains in unity and strength"9 (Parliamentary Debates, April 27, 1994). These views were echoed in the Parliamentary debates and many remarks similar in tone and emphasis were made by elected officials. An MP declared that we are most united on a hockey rink as we set aside backgrounds, English, French, ethnic, and as we work together as a nation.

Representatives of the sovereignist Bloc Québécois were up to the challenge of debating Bill C-212 even though it was cast in such patriotic terms. The Bloc did not shy away from the discussions; its members even joined in the affirmation of pride in past hockey achievements, even though they focused on Quebec-born hockey players and on their contri- 
bution to the sport. High on their list was Maurice Richard, who led the Montreal Canadians hockey team to several championships and who was the first player to have scored 50 goals in one NHL season. Maurice Richard was included in the federalist parliamentarians' list of Canadian legends, but the Bloc Québécois MPs referred to him as a powerful symbol for Quebecers. Maurice Richard was presented as a symbol of French Canadian success within Canada and as a widely recognized symbol of Quebec's Quiet Revolution of the 1960s characterized by the struggle for equality between French and English speakers. ${ }^{10}$

The Bloc Québécois confined their nostalgic reflection to the Montreal Canadians hockey team and referred to several of the leading players throughout the team's history as French-speaking stars. This included such names as Phil Goyette, Bernard Geoffrion, Jacques Plante, Jean Béliveau, Jacques Laperrière, Henri Richard, Guy Lafleur, Jacques Lemaire, Guy Lapointe, Patrick Roy, Guy Charbonneau. Bloc Québécois MPs also pointed out that English players had also contributed to the Montreal Canadians and that: "some French-speaking players also won fame with other teams." 11

Declaring that hockey will be one of the things that ultimately keep us together as a nation, MP Dennis Mills said he simply could not imagine that one day the Montreal Canadians hockey team would be called the Montreal Blocs. The Bloc Québécois did not wish to reject something viewed favourably by a majority of Canadians and Quebecers. One Bloc MP remarked that making hockey and lacrosse Canada's national sports added to existing symbols such as the beaver, the national anthem and the Canadian flag. In the final analysis, the Bloc MP warned that a sovereign Quebec would likely confer similar status upon these sports. The following statement was in response to Dennis Mills' comment: "The Montreal Blocs could very well play against the Toronto Maple Leafs. That would be a good representation of the two Canadian nations, once sovereign."12

The Bloc described its consent to support the recognition of hockey and lacrosse as Canada's national sports as a goodwill gesture. While congratulating MP Nelson Riis for his determination for wanting to have hockey recognized as a national sport, Bloc Québécois MP Antoine Dubé stated that nothing would prevent the two countries, in the aftermath of a sovereignist victory, from sharing the same national sports.

\section{Lacrosse}

As noted earlier, the formal recognition of Aboriginal Peoples constituted an ongoing challenge to those involved in the formal acknowledgement of the founding characteristics of Canadian society. Supporters of the recog- 
nition of lacrosse as an official sport contended that their efforts were rooted in Canada's past and, in particular, in the contribution of Canada's Aboriginal Peoples. The earliest European record of lacrosse dates back to the early 1800 s when French missionaries reported seeing Aboriginal people playing a game with sticks and a ball. They called it "à la crosse" because the sticks reminded them of the bishop's crozier or "crosse." In the early 1800 s, white settlers in Montreal took up the game. Virtually every nation in North America had some form of ball and stick game and each had its own name for the game. The Ojibway played Baggataway while the Mohawk played Tewaarathon. Lacrosse, which the Native People of North America knew under many different names such as Baggataway or Tewaarathon, played a significant role in the community and in the religious life of tribes across the continent for many years.

The game of lacrosse was quickly winning the loyalty and interest of the newest North Americans. Lacrosse was named Canada's National Game by Parliament in 1859. In 1867, the Montreal Lacrosse Club, headed by Dr. George Beers, organized a conference in Kingston in order to create a national body whose purpose would be to govern the sport throughout the newly formed country. In much the same way that hockey is described as contributing to unite English and French Canadians, lacrosse was said to establish a bond between Aboriginal nations and European settlers. ${ }^{13}$ European concepts of structure and rules were added to the religious and social rituals of the first North Americans, resulting in one of the first symbols of the new Canada. Lacrosse remains a significant contribution of Aboriginal culture to North American society. In fact, it is viewed as the oldest game in the United States. Canadians are credited with introducing the game to the United States, England, Ireland, and Scotland. ${ }^{14}$

This recognition was widely documented by recognized authorities including researchers, sports writers, and historians of the late $19^{\text {th }}$ and early $20^{\text {th }}$ centuries. The earliest source is Scribner's Magazine (volume 14, May to October 1877) where we find the statement: "The game of lacrosse was adopted as the national game of Canada on July 1, 1859."15 The $11^{\text {th }}$ edition of the Encyclopaedia Britannica (1911) refers to lacrosse as "... the national game of Canada." 16 In 1904 Canada sent its first delegation to the Olympic Games and lacrosse was one of the team sports in which it participated. Lacrosse is the only Olympic team sport where Canada won more medals than all the other countries combined. Those who supported the recognition of lacrosse in the national debate pointed out that many hockey legends played both sports, among them former National Hockey League stars Bobby Orr and Wayne Gretzky who used lacrosse to sharpen their hockey skills. During his term as Prime Minister, the Right Hon. Lester B. Pearson became the honorary chairman of the Canadian Lacrosse Association. 
In the early $20^{\text {th }}$ century, lacrosse was the dominant sport in Canada and there was much activity at both the amateur and professional levels. During the 1930s a rethinking of the relationship of the two most popular games, lacrosse and hockey, resulted in the creation of indoor lacrosse, also known as Box Lacrosse or Boxla. The game was built upon speed and action and very quickly won support from the organized leadership. Lacrosse is described today as a combination of football, hockey, and basketball. By the mid-1930s, the field game had been completely replaced by Boxla and the box version became the official sport of the Canadian Lacrosse Association. It is worth noting that some historians view this "seasonal" reorganization as a major cause of the decline of lacrosse.

In 1964, a bill was introduced in the House of Commons to declare hockey Canada's national sport. An opposing bill countered that although the official status of lacrosse had not been legislated, it was viewed as Canada's official game by important segments of the population. This second bill sought the official recognition of lacrosse. Ultimately, neither bill was debated by Parliament. A few years later on the occasion of Canada's $100^{\text {th }}$ birthday the issue again arose and the outcome was similar. Some twenty-seven years later, in 1994, Aboriginal leaders objected to the government bill that proposed the recognition of ice hockey as Canada's national sport. They argued that by excluding the recognition of lacrosse, the bill ignored an important Aboriginal contribution to Canadian history and society. The parliamentarians who supported the recognition of lacrosse stated that they were not out to undermine hockey and that they believed that it was: "... time for Canadians to realize the cultural contribution of our first people, our truly first people not just in sport but in many things."17 The passage of a bill recognizing only hockey would have been viewed negatively by the Aboriginal Peoples, much like the rejection of the Meech Lake Accord, which contained the distinct Quebec society clause, resulted in negative sentiments in Quebec.

In response, the bill was amended "to recognize hockey as Canada's National Winter Sport and lacrosse as Canada's National Summer Sport." ${ }^{18}$ Some officials stated that the recognition would give them an opportunity to learn more about lacrosse. One Member of Parliament, while not opposing the recognition of lacrosse, stated that in his constituency in southwestern Ontario the summertime sport of choice was baseball and always had been. This elected official did not wish to denigrate the sport of lacrosse; he simply wanted to point out that, unlike hockey, it was not played in all parts of the country. It was MP Pat O'Brien who, while describing hockey as the national obsession of Canadians, demonstrated his concern to include a Canadian sporting tradition that predated Confederation when he introduced an amendment 
to recognize both ice hockey and lacrosse as national sports of Canada. He contended that:

While many Canadians would certainly view the national sports status of ice hockey as a natural expression of the Canadian reality, the concept has been on ice for decades. Canadians have long recognized the significance of another sport which also originated in Canada and which is played all over the world today. Our proposed amendment would allow for the inclusion of Canada's long tradition in the sport of lacrosse and would resolve an issue that has been left on the bench since Confederation. ${ }^{19}$

More than a decade after the official recognition of hockey and lacrosse as Canada's national sports, sports remain an important part of our national identity and the government is perhaps now more focused on the contribution of sports on unity and cohesion across the country. Although the connection between achievement in sports and national pride is so self-evident for many, it merits some examination. According to a 2005 report prepared for Sports Canada by the Conference Board of Canada, sports give us pleasure, help define us and our communities, and contribute to the sense of what it means to be Canadian (Conference Board of Canada, 2005): ${ }^{20}$ An international survey conducted in 2004 revealed that some $85 \%$ of Canadians were proud when their country did well in international sports. Canada ranked $14^{\text {th }}$ in a 34 nation International Social Survey Program (ISSP) for the level of national pride exhibited in international sports achievements (see Table 1). Feeling good about national sports performance does not imply that a country is proud of its actual achievements. Pride is often contingent upon a country's expectations vis-à-vis such achievements. Overall some $88 \%$ of Canadians say they are proud of their country's achievements in sports. This is above the combined average for all the countries surveyed (81\%) yet below such nations as Ireland, Australia and the United States (see Table 2). However, hockey's ability to remain the principal source of such pride may depend on its ability to broaden its viewership and participant base within the country's growing non-European population.

Since the 1960s, perhaps the most important feature of Canada's demographic evolution has been the growing presence of non-Europeans. Statistics Canada projects that the non-European segment of the Canadian population could top eight million by 2017 , representing a two-fold increase since 2001. By 2017, roughly one in five Canadians will be of non-European origin, an increase from slightly more than one in eight in 2001. The population of European origin will continue to grow, albeit at a much slower pace (between $1 \%$ and $7 \%$ between 2001 and 2017). 
These demographic changes will undoubtedly influence cultural choices and practices including those widely considered to be fundamental to Canada's self-definition. This is true in the area of sports where changing demographics are among a number of factors that influence the preferred choices of Canadians. As the composition of the nation's population rapidly evolves so too do the sports that its peoples choose to watch and/or play. Regarded as the dominant sport in a world marked by increasing globalization, soccer is perhaps seen as the principal competition to the supremacy of hockey in Canada. This is not to imply that soccer will one day supplant hockey; rather, it suggests that it will diminish the extent of its dominance nationally. If this occurs, and there is evidence that it is already underway, it will not be solely attributable to the influx of nonEuropean immigrants and to their descendants. The appeal of soccer is strong among many Canadians of European background. They are connected, and in many instances reconnected, via satellite and the internet to the sport that dominates most of the European continent. Indeed far more Canadians watched Italy's victory over France in the 2006 FIFA World Cup than the Edmonton Oilers' defeat by the Carolina Hurricanes in the final game of the National Hockey League Championships. In a 2006 survey of several ethnic groups in Canada's major cities, pollster Kaan Yigit found that although its margin of dominance will shrink, hockey will remain the sport most followed in Toronto, Montreal and Vancouver over the next decade. He found that the potential market growth of basketball and soccer among the fast-growing population of non-European origin is much greater than it is for hockey (Solutions Group, May 8, 2006). . $^{21}$.

Hockey also faces stiff competition as a sport played by Canadians. Based on the membership in Canadian sports federations, in 2005, soccer was well ahead of hockey with over 840,000 registered players while Hockey Canada claimed 550,000 for that same year. The number of registered soccer players for 2005 was nearly double the number reported by Soccer Canada a decade earlier. Given that this membership is mostly comprised of younger Canadians, the changing demographic trends will likely contribute to a widening of the membership gap. Where Canada successfully competes internationally in hockey, the country has yet to enjoy any meaningful success in soccer on the world stage. The growth in popularity of soccer may result in reinforcing the diaspora ties for many European and non-European immigrants and their descendants who favour the teams of the countries of origin.

\section{The Evidence on Sports Consumption in Canada}

Data from surveys conducted in recent years provide a somewhat diverse portrait of changing trends in the sports viewed and played by Canadians. 
Interpretations of survey data depend upon the manner in which questions were put to the population and the sports included in the choices made available to respondents. While ethnic background is an important consideration in understanding patterns of sports consumption, factors such as age, gender and region are equally, if not more important. The intersection between such demographic characteristics is very relevant. For example, it would be interesting to know the sports consumption habits of young members of ethnic communities.

A 2004 survey conducted by the Conference Board of Canada points out that Canadians participate in many sports but tend to concentrate on a few. According to the Conference Board, out of nearly 100 sports played, involvement is strongly focused in about a dozen sports of which ice hockey, golf, soccer, baseball, basketball, volleyball, skiing, swimming and cycling are the top choices. On the basis of the polling data, hockey has the single largest number and share of "active participants" as opposed to the number of registered members in sports associations. Hockey also has the largest number and share of volunteers and attendees. Soccer has the second largest number and share of volunteers and attendees, but only the fifth number of active participants. Golf, a summer sport with a disproportionately greater number of persons in the 45 plus age category, is second in the number of active participants, closely behind hockey (see Table 3).

A survey conducted by the firm Leger Marketing for the Association for Canadian Studies in the fall 2006 explores the population's preferences in sports participation on the basis of language and gender. Onefifth of the francophones surveyed chose hockey as the sport in which they prefer to participate. Some $13 \%$ of anglophone Canadians surveyed said hockey is the sport they preferred to play. Eleven percent of anglophone respondents indicated that they prefer to participate in swimming, golf and baseball. Soccer was a clear favourite among the allophone respondents. In the 18 to 44 age groups, hockey and soccer were almost equally preferred. Golf emerges as the favourite sport in which to personally participate for those over the age of 55 (see Table 5).

\section{Sports Followed by Canadians: Viewing and Listening Habits}

When it comes to the sports that Canadians follow, University of Lethbridge sociologist Reginald Bibby believes that it is an exaggeration to say that they live or die by the National Hockey League. Based on data compiled in 2005, he maintains that in the past few years the Canadian Football League was followed by more Canadians than the National Hockey League (Maclean's Magazine, July 1, 2006). Bibby explains that the 2004-2005 players strike resulting in the cancellation of the 
2004-2005 National Hockey League season, the retirement of celebrity players like Wayne Gretzky, poor team performance and the loss of the Winnipeg and Quebec City franchises contributed to a drop in the number of Canadians following the game.

Other survey data suggest that while hockey is clearly facing competition as the preferred sport of play of Canadians, it is faring better as a "viewer" sport, as one listened to and read about by the population. The data from two surveys conducted in 2003 and 2006 that looked at the number of Canadians following different sports (not just the professional teams) provide a less pessimistic view of the state of hockey, although there is still cause for concern.

Nearly three in ten Canadians surveyed by Environics in January 2003 said they follow hockey through television, radio and in newspapers more than any other sport. Its popularity varies from region to region with Quebec, the home province of the legendary Montreal Canadians, somewhat less likely to follow hockey than other Canadians. The popularity of hockey is greater for Canadians under the age of 30 . With respect to the other sports followed by Canadians, preferences vary considerably. While important segments of Canadians follow football, baseball, and golf as noted earlier, the biggest threat to hockey's ongoing dominance may come from soccer and basketball. Non-European immigrants are more likely to follow soccer than hockey. As noted in the tables, when it comes to viewing, listening, or reading about sports, Quebecers are somewhat more likely to prefer amateur hockey and figure skating than other Canadians. In addition, in Quebec, tennis and soccer have a greater viewing and listening audience than is the case elsewhere in the country. The proportion of respondents that do not follow any sport whatsoever is higher in Quebec than it is elsewhere in Canada. In 2003, the proportion of Quebecers who followed baseball and basketball was particularly low compared to other parts of the country (see Table 6).

When the sports viewing and listening habits of Canadians living in larger cities are considered, hockey is the sport of choice for $38 \%$ of Vancouverites, $31 \%$ of Torontonians and only $19 \%$ of Montrealers. In fact, a majority of the Vancouver respondents prefer to watch or listen to winter sports. Canadian football attracts a somewhat higher percentage of viewers in Montreal (6\%), than in Vancouver (2\%) and Toronto (1\%). On the basis of gender, while women $(23 \%)$ were somewhat less inclined to follow hockey than men $(35 \%)$, they had a marked preference for figure skating $(13 \%)$ compared to their male counterparts $(1 \%)$. Women were also more likely to say that they did not follow any sport (23\%) than men $(12 \%)$. As observed below, hockey is much more popular for the groups between the ages of 18 to 44 than for the groups over 45 . Figure skating, 
golf, and baseball seem to be more popular with the older group. The respondents aged between 18 to 29 preferred to watch and listen to hockey over soccer. This is likely attributable to the effect of demographic change and the fast growing share of non-Europeans within that age cohort (see Table 7).

When the menu of sport choices offered to Canadians is reduced to include only the dominant sports, survey respondents tend to pick hockey well over any other spectator sports. This suggests that hockey may stand to lose more as a result of the increased choices offered to Canadians through various media. In the fall 2006 Leger Marketing survey, $45 \%$ of the respondents chose hockey as the sport that they most prefer to follow in the media.. No other single sport appears to compete with hockey. As for the other sports, the preferences of Canadians are divided relatively equally across the board. There are, however, some significant regional differences. Hockey has somewhat fewer fans on the Prairies than in other parts of Canada. As for football, it is followed by more than one out of five people in the Prairie region (both Winnipeg and Regina have Canadian Football League teams but no professional hockey clubs). In Quebec, Ontario and British Columbia soccer finishes second while baseball holds down second spot in the Atlantic (see Table 8). It is interesting to contrast the 2003 and 2006 survey results related to the popularity of hockey in Quebec. While the earlier survey offered a greater range of choices, it is reasonable to conclude that following the National Hockey League players' strike, hockey has rebounded in the province. The Leger Marketing survey found the strongest support for hockey in the youngest cohort of respondents; the majority of the 18-24 category claimed that hockey is the spectator sport that they prefer to follow in the media (see Table 9). However, Canadians whose mother tongue is neither English nor French (allophones) followed soccer as much as hockey. English Canada chose football over soccer whereas francophone Canadians are equally divided between the two sports (see Table 10).

\section{Hockey's Prospects: Looking to the Future}

Although hockey seems to be doing reasonably well as a spectator sport in Canada, when asked what the future holds for the sport widely regarded as the country's national game, many Canadians are not as confident. When asked which spectator sport will be dominant by 2020 , a majority of Canadians said it would be hockey $(58 \%)$ with soccer finishing in second place (28\%) But the prospects for hockey's dominance by 2020 were the object of far greater optimism for the younger generation than for the older one. The 2006 Leger Marketing survey reveals that while $80 \%$ of Canadians between the ages of 18 and 24 believe that hockey will remain dominant by 2020 , that figure drops to about $45 \%$ for those 
respondents over the age of 55 . Within that group, some $35 \%$ predict that soccer will be the country's most popular spectator sport by 2020 . Reviewing the results regionally, it is interesting to note that Quebecers are the least optimistic about the future prospects of hockey as a spectator sport. Indeed, Quebec is the only region surveyed where more people believe soccer will be the most popular spectator sport by 2020 . Some $45 \%$ of Quebecers polled predicted that soccer would remain dominant over hockey $(36 \%)$. Paradoxically the allophones surveyed were more likely to think that hockey would be the most popular $(62 \%)$ and soccer in second (24\%) and this despite the fact that this group watches and plays the latter sport significantly more frequently than either anglophones or francophones. For their part, anglophone Canadians are much more sanguine regarding the future prospects for hockey with nearly two-thirds saying it would dominate by 2020 , while just under four in ten francophones share that point of view.

Yet another possible challenge to hockey's future influence within the Canadian population of non-European origin will be the sport's capacity to involve players at the highest levels from this segment of the population. To the extent that certain ethnic groups will prefer in the future to follow sports that include at least some participants from their particular cultural background, professional hockey could face an important challenge. Indeed, 2001 census figures reveal that with the exception of persons who identified themselves as Black on the census question related to visible minority identification, Canada's professional sports have little, and in some instances, no representation from most of the non-European origin groups (see Table 11). Given the demographic changes anticipated in the decades ahead for Canada, this surely represents an issue that will warrant attention of those marketing various sports in Canada.

\section{Conclusion}

The Canadian Broadcasting Corporation's 2006 televised series, Hockey: A People's History, is described as "...chronicling the story of a game and the soul of a nation. Born as a game of survival against the snow and ice of a Canadian winter, hockey gave a new country its first heroes and champions...hockey is where Canada's cultures collide and rivalries divide. It's also a game that unites us like nothing else can." 22 Douglas Fisher, a politician and the author of the book Canada's Sporting Heroes, once said that: "most of our shared experiences and values from Bonavista to Vancouver Island are through politics and sport. It is ultimately woven in our Canadian self-image and our mythology." 23

MP Pat O'Brien proudly boasted that the winning goal in the final game in the 1972 series between Canada and the Soviet Union was scored 
by Paul Henderson with the help of Yvan Cournoyer and Phil Esposito. O'Brien concluded by saying: "That is the kind of co-operation we need in this country: An English Canadian, a French Canadian and an Italian Canadian working together to help us win a hockey series." 24 In spite of this sentiment, hockey's growth potential will, at least to some extent, depend on the sport's capacity to attract non-Europeans and the co-operation described by O'Brien will need to include several other groups.

Despite the mixed evidence from existing data, during the early part of the $21^{\text {st }}$ century and for the foreseeable future, hockey will continue to be the sport followed by most Canadians. Although it is being challenged by soccer as the sport that Canadians play most frequently, the competition seems to be greatest within the younger segment of Canada's population. This is attributable in part to rapidly shifting demographics, more specifically to the increasing presence of non-Europeans. If soccer's popularity as a sport played by Canadians continues to grow, it will surely create demands for opportunities to follow the sport professionally. Those in the business of marketing hockey in Canada are likely paying close attention to these trends and will likely develop strategies to keep the sports dominant. It has been argued that since hockey is a winter sport, and soccer largely a summer game, the two sports should complement one another rather than be in competition. To date, no study has been designed to examine carefully the seasonal patterns of sports participation and consumption in Canada and to determine the possible combinations of preferences of multiple sports consumers. Such information may be invaluable in an environment characterized by an increasing competition for attention and resources, and where co-operation may be beneficial to the Canadian sports community.

\section{Endnotes}

1. Parliamentary Debates, House of Commons Canada, National Sport Act Statement by Members Private Members' Business, Wednesday, April 27, 1994-hereafter Parliamentary Debates, April 27, 1994.

2. Paul Kitchen "From Mesopotamia to Montreal: What Is Hockey and Where Did it Start?" in Canadian Sports Studies, Montreal: Association for Canadian Studies, March 2004.

3. Cameron, David. The Referendum Papers: Essays on Secession and National Unity, Toronto: University of Toronto Press, 1999.

4. Parliamentary Debates, April 27, 1994.

5. Parliamentary Debates, April 27, 1994.

6. Mclean, Stuart, Welcome Home: Travels in Smalltown Canada, Toronto: Penguin Books, 1992.

7. Parliamentary Debates, April 27, 1994.

8. Ibid. 
9. Ibid.

10. Ibid.

11.Ibid.

12. Ibid.

13. Mitchell, Mike, Director, North American Indian Travelling College "Lacrosse: A Gift for People of Canada" Canadian Lacrosse Association, http://www.lacrosse. ca/nationalsport.asp.

14. Ibid.

15.Parliamentary Debates, April 27, 1994.

16. Ibid.

17.Ibid.

18. Ibid.

19. Ibid.

20. "National Household Survey on Participation in Sport," Conference Board of Canada, December 2004.

21. Yigit, Kaan, "Diversity in Canada Study Results: Basketball Fastest Growing Sport in Canada," Solutions Group, May 8, 2006.

22. Bibby, Reginald, as cited in "How Canadian Are You? The 2006 Canada Day Poll." Maclean's Magazine, July 1, 2006.

23.Canadian Broadcasting Corporation (2006) Hockey: A People's History, http://www.cbc.ca/hockeyhistory/episodesummary/01/post/index.html.

24. Fisher, Douglas, as cited in Parliamentary Debates, April 27, 1994. 


\section{TABLE 1}

When my country does well in international sports it makes me proud to be (nationality)

\begin{tabular}{|c|c|c|c|}
\hline & COMBINED & AGREE STRONGLY & AGREE \\
\hline Ireland & 95.1 & 55.9 & 39.2 \\
\hline Venezuela & 93.4 & 68.7 & 24.7 \\
\hline Slovenia & 91.5 & 51.1 & 40.4 \\
\hline Poland & 91.4 & 49.5 & 41.9 \\
\hline Hungary & 91.3 & 56.8 & 34.5 \\
\hline Japan & 90.2 & 62.0 & 28.2 \\
\hline Russia & 89.6 & 58.8 & 30.8 \\
\hline South Korea & 89.4 & 30.3 & 59.1 \\
\hline South Africa & 88.0 & 47.4 & 40.6 \\
\hline Slovak Republic & 87.1 & 37.6 & 49.5 \\
\hline Czech Republic & 86.8 & 52.6 & 34.2 \\
\hline Portugal & 86.4 & 35.7 & 50.7 \\
\hline New Zealand & 85.6 & 42.3 & 43.3 \\
\hline Canada & 85.1 & 39.2 & 45.9 \\
\hline Philippines & 84.5 & 45.6 & 38.9 \\
\hline Latvia & 82.4 & 35.9 & 46.5 \\
\hline Australia & 79.7 & 34.8 & 44.9 \\
\hline Denmark & 77.7 & 25.2 & 52.5 \\
\hline Israel (Jewish Population) & 77.4 & 52.0 & 25.4 \\
\hline Sweden & 76.5 & 28.7 & 47.8 \\
\hline United States & 75.8 & 34.6 & 41.2 \\
\hline France & 75.6 & 10.6 & 65.0 \\
\hline Austria & 74.2 & 43.7 & 30.5 \\
\hline Spain & 73.9 & 17.4 & 56.5 \\
\hline Uruguay & 73.7 & 28.3 & 45.4 \\
\hline Chile & 73.1 & 27.2 & 45.9 \\
\hline Germany East & 72.6 & 17.1 & 55.5 \\
\hline Norway & 72.6 & 22.6 & 50.0 \\
\hline Switzerland & 72.0 & 19.2 & 52.8 \\
\hline Great Britain & 71.9 & 29.0 & 42.9 \\
\hline Finland & 56.5 & 14.4 & 42.1 \\
\hline Germany West & 55.9 & 16.7 & 39.2 \\
\hline Taiwan & 51.1 & 9.7 & 41.4 \\
\hline Total & 82.7 & 41.6 & 41.1 \\
\hline
\end{tabular}

Source: International Social Science Program Survey, 2004 (the survey was conducted in 34 countries with national samples ranging between 700 and 2300 respondents. In Canada there were approximately 1150 respondents and the survey was conducted by the Carleton University Survey Centre). 
Giving Hockey's Past a Future: When Identity Meets Demography in Canadian Sports

TABLE 2

Pride: Country's Achievements in Sports

\begin{tabular}{|c|c|c|c|}
\hline & COMBINED PRIDE & VERY PROUD & $\begin{array}{l}\text { SOMEWHAT } \\
\text { PROUD }\end{array}$ \\
\hline Ireland & 97.3 & 60.6 & 36.7 \\
\hline New Zealand & 95.4 & 61.4 & 35.0 \\
\hline Australia & 94.1 & 58.5 & 35.6 \\
\hline Hungary & 93.7 & 46.1 & 47.6 \\
\hline Venezuela & 93.4 & 68.7 & 24.7 \\
\hline United States & 90.4 & 44.8 & 45.6 \\
\hline Czech Republic & 89.7 & 41.0 & 48.7 \\
\hline Latvia & 89.2 & 40.8 & 48.4 \\
\hline Japan & 89.2 & 37.5 & 51.7 \\
\hline South Korea & 89.2 & 30.1 & 59.1 \\
\hline Austria & 88.3 & 49.3 & 39.0 \\
\hline South Africa & 88.0 & 47.4 & 40.6 \\
\hline Canada & 87.7 & 32.2 & 55.5 \\
\hline Slovak Republic & 87.3 & 37.6 & 49.7 \\
\hline Portugal & 86.4 & 35.7 & 50.7 \\
\hline Spain & 86.0 & 21.4 & 64.6 \\
\hline Slovenia & 85.9 & 33.1 & 52.8 \\
\hline Sweden & 85.5 & 34.5 & 51.0 \\
\hline Philippines & 84.3 & 40.0 & 44.3 \\
\hline Germany East & 84.3 & 18.5 & 65.8 \\
\hline Norway & 79.8 & 28.3 & 51.5 \\
\hline Denmark & . $\quad 77.3$ & 25.2 & 52.1 \\
\hline France & 76.1 & 10.7 & 65.4 \\
\hline Russia & 75.7 & 26.2 & 49.5 \\
\hline Uruguay & 73.7 & 28.3 & 45.4 \\
\hline Chile & 73.1 & 27.2 & 45.9 \\
\hline Switzerland & 72.0 & 19.2 & 52.8 \\
\hline Poland & 72.0 & 14.8 & 57.2 \\
\hline Germany West & 71.7 & 16.7 & 55.0 \\
\hline Great Britain & 69.1 & 18.1 & 51.0 \\
\hline Finland & 56.5 & 14.4 & 42.1 \\
\hline Taiwan & 51.1 & 9.7 & 41.4 \\
\hline Israel (Jewish Population) & 42.6 & 10.1 & 32.5 \\
\hline Total & 81.0 & 33,8 & 47.2 \\
\hline
\end{tabular}

Source: ISSP 2004. 
TABLE 3

Most Popular Sports, by Type of Participation, Adult Population



Source: Conference Board of Canada. National Household Survey on Participation in Sport. December 2004. 
TABLE 4

Which do you consider your favourite sport to personally participate in?

\begin{tabular}{lrrr}
\hline \multicolumn{3}{c}{ LANGUAGE } \\
& FRANCOPHONE & ANGLOPHONE & ALLOPHONE \\
\hline Hockey & $20 \%$ & $13 \%$ & $8 \%$ \\
Soccer & $7 \%$ & $8 \%$ & $23 \%$ \\
Swimming & $9 \%$ & $11 \%$ & $10 \%$ \\
Golf & $8 \%$ & $11 \%$ & $10 \%$ \\
Baseball & $6 \%$ & $11 \%$ & $7 \%$ \\
Basketball & $4 \%$ & $4 \%$ & $8 \%$ \\
Tennis & $6 \%$ & $3 \%$ & $7 \%$ \\
Other & $27 \%$ & $21 \%$ & $14 \%$ \\
None & $12 \%$ & $18 \%$ & $14 \%$ \\
\hline
\end{tabular}

Source: Leger Marketing for the Association for Canadian Studies, September 21-27, 2006.

\section{TABLE 5}

Which do you consider your favourite sport to personally participate in?

\begin{tabular}{|c|c|c|c|c|c|c|}
\hline & \multicolumn{6}{|c|}{ AGE } \\
\hline & $18-24$ & $25-34$ & $35-44$ & $45-54$ & $55-64$ & 65 AND OVER \\
\hline Hockey & $19 \%$ & $15 \%$ & $12 \%$ & $16 \%$ & $9 \%$ & $13 \%$ \\
\hline Soccer & $16 \%$ & $17 \%$ & $13 \%$ & $6 \%$ & $5 \%$ & $5 \%$ \\
\hline Swimming & $9 \%$ & $9 \%$ & $13 \%$ & $12 \%$ & $10 \%$ & $6 \%$ \\
\hline Golf & $4 \%$ & $8 \%$ & $10 \%$ & $10 \%$ & $15 \%$ & $15 \%$ \\
\hline Baseball & $10 \%$ & $9 \%$ & $11 \%$ & $8 \%$ & $8 \%$ & $7 \%$ \\
\hline Basketball & $14 \%$ & $7 \%$ & $3 \%$ & $3 \%$ & $3 \%$ & - \\
\hline Tennis & $2 \%$ & $5 \%$ & $6 \%$ & $4 \%$ & $4 \%$ & $4 \%$ \\
\hline Other & $21 \%$ & $22 \%$ & $23 \%$ & $25 \%$ & $21 \%$ & $12 \%$ \\
\hline None & $5 \%$ & $8 \%$ & $9 \%$ & $15 \%$ & $26 \%$ & $36 \%$ \\
\hline
\end{tabular}

Source: Leger Marketing for the Association for Canadian Studies, September 21-27, 2006. 


\section{TABLE 6}

What, if any, do you consider to be your favourite spectator sport to watch on TV, listen to on radio or follow in the newspapers?

\begin{tabular}{lccccc}
\hline & \multicolumn{3}{c}{ ATL. } & \multicolumn{3}{c}{ WESTERN } \\
& TOTAL & PROV. & QUEBEC & ONTARIO & CAN. \\
\hline Hockey (professional) & 29 & 30 & 20 & 32 & 31 \\
Figure skating & 7 & 8 & 10 & 6 & 6 \\
Hockey (amateur) & 5 & 6 & 8 & 4 & 4 \\
Baseball & 5 & 7 & 3 & 6 & 3 \\
Soccer & 4 & 3 & 6 & 5 & 3 \\
Golf & 4 & 4 & 4 & 6 & 3 \\
Football (NFL) & 4 & 3 & 4 & 6 & 3 \\
Football (CFL) & 3 & 1 & 4 & 2 & 5 \\
Other & 21 & 20 & 20 & 17 & 25 \\
None, do not follow sports & 18 & 18 & 21 & 16 & 17 \\
\hline
\end{tabular}

Source: Environics for the Association for Canadian Studies, January 2003.

\section{TABLE 7}

What, if any, do you consider to be your favourite spectator sport to watch on TV, listen to on radio or follow in the newspapers?

AGE

18 TO 2930 TO $44 \quad 45$ TO 5960 OR MORE

\begin{tabular}{lcccc}
\hline Hockey (professional) & 34 & 34 & 23 & 21 \\
Figure skating & 3 & 6 & 10 & 12 \\
Hockey (amateur) & 5 & 5 & 5 & 5 \\
Baseball & 3 & 3 & 6 & 8 \\
Soccer & 7 & 5 & 4 & 2 \\
Golf & $*$ & 3 & 5 & 10 \\
Football (NFL) & 6 & 4 & 5 & 2 \\
Football (CFL) & 5 & 3 & 3 & 4 \\
Auto racing & 3 & 4 & 4 & 1 \\
Basketball & 5 & 3 & 3 & $*$ \\
None, do not follow sports & 14 & 17 & 19 & 21
\end{tabular}

Source: Environics for the Association for Canadian Studies, January 2003. 
TABLE 8

Among the following, which is your favourite spectator sport to follow in the media (TV, Radio, Newspaper, etc.)... ?

\begin{tabular}{lccccccc}
\hline & & & & & & \multicolumn{2}{c}{ BRITISH } \\
& CANADA & ATLANTIC & QUEBEC & ONTARIO & PRAIRIES & ALBERTA COLUMBIA \\
\hline Hockey & 45 & 45 & 47 & 44 & 37 & 52 & 42 \\
Football & 12 & 5 & 12 & 9 & 22 & 13 & 14 \\
Soccer & 12 & 9 & 15 & 13 & 5 & 5 & 16 \\
Baseball & 6 & 16 & 3 & 7 & 7 & 3 & 6 \\
Basketball & 4 & 3 & 2 & 7 & 3 & 3 & 2 \\
Other & 7 & 2 & 6 & 6 & 7 & 10 & 9 \\
None & 14 & 20 & 14 & 15 & 18 & 12 & 11 \\
\hline
\end{tabular}

Source: Leger Marketing for the Association for Canadian Studies, September 21-27, 2006.

\section{TABLE 9}

Among the following, which is your favourite spectator sport to follow in the media (TV, Radio, Newspaper, etc.)...?

\begin{tabular}{lcccccc}
\hline & & \multicolumn{5}{c}{ Age } \\
& $18-24$ & $25-34$ & $35-44$ & $45-54$ & $55-64$ & 65 \\
\hline Hockey & $54 \%$ & $50 \%$ & $42 \%$ & $42 \%$ & $42 \%$ & $40 \%$ \\
Football & $10 \%$ & $11 \%$ & $12 \%$ & $14 \%$ & $11 \%$ & $11 \%$ \\
Soccer & $10 \%$ & $16 \%$ & $16 \%$ & $10 \%$ & $8 \%$ & $10 \%$ \\
Baseball & $3 \%$ & $3 \%$ & $5 \%$ & $7 \%$ & $12 \%$ & $9 \%$ \\
Basketball & $13 \%$ & $3 \%$ & $3 \%$ & $3 \%$ & $2 \%$ & $2 \%$ \\
Other & $2 \%$ & $4 \%$ & $10 \%$ & $5 \%$ & $8 \%$ & $10 \%$ \\
None & $8 \%$ & $12 \%$ & $12 \%$ & $19 \%$ & $16 \%$ & $18 \%$ \\
\hline
\end{tabular}

Source: Leger Marketing for the Association for Canadian Studies, September 21-27, 2006. 
TABLE 10

Among the following, which is your favourite spectator sport to follow in the media (TV, Radio, Newspaper, etc.)... ?

\begin{tabular}{lccc}
\hline & \multicolumn{2}{c}{ LANGUAGE } & \\
& FRANCOPHONE & ANGLOPHONE & ALLOPHONE \\
\hline Hockey & $51 \%$ & $47 \%$ & $30 \%$ \\
Football & $10 \%$ & $12 \%$ & $10 \%$ \\
Soccer & $10 \%$ & $7 \%$ & $30 \%$ \\
Baseball & $4 \%$ & $8 \%$ & $4 \%$ \\
Basketball & $2 \%$ & $3 \%$ & $11 \%$ \\
Other & $7 \%$ & $7 \%$ & $5 \%$ \\
None & $16 \%$ & $16 \%$ & $9 \%$ \\
\end{tabular}

Source: Leger Marketing for the Association for Canadian Studies, September 21-27, 2006.

\section{TABLE 11}

Numbers of Canadians by Visible Minority Status Reporting Occupations as Professional Athletes, 2001 (Where the number is less than 10, the Census lists the figure at 0 )

\begin{tabular}{llll}
\hline & $\begin{array}{l}\text { TOTAL - } \\
\text { POPULATION 15+ IN } \\
\text { LABOUR FORCE }\end{array}$ & FEMALE & MALE \\
CANADA & & & \\
\hline Occupation: Athletes & & & \\
Total - Population 15+ & 2595 & 380 & 2220 \\
in labour force & 230 & 0 & 220 \\
Visible minority population & 130 & 0 & 125 \\
Black & 0 & 0 & 0 \\
South Asian & 0 & 0 & 0 \\
Chinese & 0 & 0 & 0 \\
Korean & 0 & 0 & 0 \\
Japanese & 0 & 0 & 0 \\
Southeast Asian & 0 & 0 & 0 \\
Filipino & 0 & 0 & 0 \\
Arab/West Asian & 0 & 0 & 0 \\
Latin American & 55 & 0 & 50 \\
All other visible minority groups & 2295 & 370 & 1930 \\
White & 70 & 0 & 70 \\
Aboriginal & & & \\
\hline
\end{tabular}

Source: Statistics Canada, Custom Tabulations for the Department of Canadian Heritage Census of Canada, 2001. 